\title{
Overtopping hazard on a rubble mound breakwater
}

\author{
Ana R. Carrasco $\uparrow$, Maria T. Reis $\uparrow \dagger$, Maria G. Neves $\uparrow \dagger$, Óscar Ferreira $\uparrow$, Ana Matias $\uparrow$, Sílvia Almeida $\uparrow$ \\ $\dagger$ CIMA, Universidade do Algarve, \\ Campus de Gambelas \\ 8005-139, Faro, Portugal \\ azarcos@ualg.pt \\ oferreir@ualg.pt \\ ammatias@ualg.pt \\ smalmeida@ualg.pt \\ $\dagger \dagger$ LNEC - National Laboratory for Civil \\ Engineering \\ Av. do Brasil, 101 \\ 1700-066 Lisboa, Portugal \\ treis@lnec.pt \\ gneves@lnec.pt
}

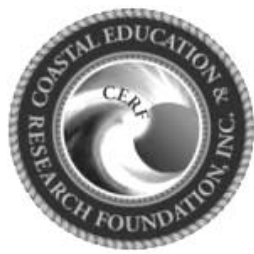

www.cerf-jcr.org

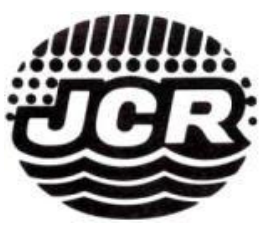

www.JCRonline.org

\section{ABSTRACT}

Carrasco, A.R., Reis, M.T., Neves, M.G., Ferreira, Ó., Matias, A, Almeida, S., 2014. Overtopping hazard on a rubble mound breakwater. In: Green, A.N. and Cooper, J.A.G. (eds.), Proceedings $13^{\text {th }}$ International Coastal Symposium (Durban, South Africa), Journal of Coastal Research, Special Issue No. 70, pp. 247-252, ISSN 0749-0208.

A major concern of coastal engineering is not only to access the damage to coastal structures by severe wave overtopping, but also the hazard imposed to users. Local hazard is often associated to the volume of overtopping water per unit of time (called overtopping discharge). Despite two decades of intensive research, it is yet not fully clear to practitioners what is the best method to compute the discharge parameter and its application on the assessment of local hazard. This work provides insight into the overtopping characterization in rubble mound breakwaters, by distinguishing different methods to assess hazardous overtopping. Fieldwork was conducted over a tidal cycle in a breakwater located at Albufeira Harbour (South coast of Portugal) under storm conditions (Hso $3 \mathrm{~m}$; Tp $9 \mathrm{~s}$ ). Mean overtopping discharges were calculated from field measurements of flow depths and velocities at the breakwater slope armour and at the impermeable crest. Two different velocities were calculated: overtopping leading-edge velocity and overtopping peak velocity. The two methods provided similar results, with higher velocities occurring during high-tide (between 2 and $10 \mathrm{~m} / \mathrm{s}$ ). Mean overtopping discharges at the beginning of the impermeable crest ranged between 0.2 and $0.8 \mathrm{l} / \mathrm{s} / \mathrm{m}$. Under the measured hydrodynamic conditions, the breakwater offers risk to all types of pedestrians.

Additionally it is shown that field measurements compare relatively well with empirical prediction methods (for the overall analysed overtopping events), namely the corrected NN_OVERTOPPING2 neural network tool. Besides contributing to the overall database on wave overtopping in coastal structures, the presented results can also be used for calibration and validation of overtopping evaluation methods (empirical formulae, artificial neural networks and numerical and physical models).

ADDITIONAL INDEX WORDS: wave, discharge, velocities, hazard, empirical prediction.

\section{INTRODUCTION}

Most sea defence structures are constructed primarily to limit overtopping volumes that might cause flooding (Shankar and Jayaratne, 2003). Flooding potential is determined from the quantity of overtopping water per unit of time (overtopping discharge) and storm duration (Chini and Stansby, 2012; Hughes et al., 2012; Tonelli and Petti, 2013). Over a storm or tide, the overtopping volumes that can be tolerated will be site specific, as the volume of water that can be permitted will depend on the size and use of the receiving area, extent and magnitude of drainage ditches, damage versus inundation curves, and return period (Pullen et al., 2007). Ideally, return periods at which overtopping hazards are analysed, and against which a defence might be designed, should be constantly set by national regulation or guidelines, yet that is not common practice (Geeraerts et al., 2007).

The main hazards on or close to sea defence structures are of death, injury, property damage or disruption from direct wave impact or by drowning (Geeraerts et al., 2007). Some guidance has been given on the basis of the tolerable discharges and overtopping volumes for a range of circumstances or uses (Pullen

DOI: 10.2112/SI70-042.1 received 30 November 2013; accepted 21 February 2014.@ Coastal Education \& Research Foundation 2014 et al., 2007; Geeraerts et al., 2007), which have been widely used in several locations. The EurOtop Manual gives guidance on allowable overtopping when people are present or vehicles are moving behind the structure.

Hazard-driven flow parameters are essentially the mean overtopping discharge and the maximum overtopping volume, as well as overtopping flow depths and velocities. The mean overtopping discharge is the most widely used to judge allowable overtopping. An extensive database on mean overtopping discharge has been gathered in the scope of the CLASH project (http//:www.clash-eu.org). However, the mean discharge does not always describe the real behaviour of wave overtopping, where only the larger incoming waves will reach the top of the structure and promote overtopping. There remain also two difficulties in specifying safety levels with reference to maximum volumes rather than to mean discharges. Firstly, methods to predict maximum volumes are available for limited structure types, and are not well-validated. Secondly, data relating individual maximum overtopping volumes to hazard levels are still very rare (Pullen et al., 2007).

The ideal situation is to instrumentally collect data at each required location and locally define the hazard thresholds. That is however a very remote possibility for the vast majority of the existing structures. Even if it is possible to collect data, often there is no constant discharge over the crest of a structure. That is the 
case when accessing very thin water layers of run-up tongues, which are common in rubble mound revetments, because they are porous and have sloping layers, dissipating a large proportion of the incident wave energy (Pullen et al., 2007). In fact, few investigations have been conducted on rough slopes of different sizes of armour (Shankar and Jayaratne, 2003). Hazard driving flow parameters are nowadays recurrently predicted based on engineering models and formulae resulting from recent experiments. Indeed, in the past two decades, wave overtopping was investigated in a large number of studies and projects, mostly of experimental nature (e.g. De Rouck et al., 2005; Van der Meer et al., 2006), which led to the development of several empirical prediction formulae and artificial neural networks (Verhaeghe, 2005; Pullen et al., 2007). Notwithstanding, the overtopping results obtained from the derived models still have a large degree of uncertainty, as the models themselves demand a continued calibration. The present work uses a dataset of collected overtopping flow depths and velocities in a rubble mound breakwater in Portugal with two aims: (a) full characterization of overtopping conditions based on fieldwork data, and (b) their comparison with mean discharges predicted by empirical tools.

\section{METHODS}

\section{Experimental setting}

Overtopping experiments were conducted at the west breakwater of Albufeira Harbour (South coast of Portugal, Figure 1) on the 19th January 2013 from 4 am till $12 \mathrm{pm}$. The chosen breakwater is a relatively low-crested structure $(4.3 \mathrm{~m}$ above mean sea level, MSL) with about $42 \%$ porosity (Eric Didier, personal communication). It is of easy access and it is often overtopped by waves higher than $3 \mathrm{~m}$ during spring tides. In the fishing harbour protected by the breakwater, small fishing boats are anchored more than $20 \mathrm{~m}$ from the rear slope of the structure. Details about the structure can be found in Didier et al. (2011). The collected and analysed data included tidal levels, wave characteristics (offshore and at the structure), and overtopping parameters (flow depth, velocity and associated discharge). For the analysis of the overtopping variability, the monitored tidal cycle was divided in several blocks of 30 minutes.

\section{Nearshore and offshore measurements}

Tidal data were obtained from Huelva tide gauge (Spain), located at about $100 \mathrm{~km}$ to the East of the study area. The recorded levels (referred to the local harbour level) were corrected for the Portuguese datum and mean sea level (MSL). A time correction ( $\sim 30$ minutes tide delay in Albufeira) was also performed. Offshore wave height (significant, Hso, and maximum, Hmaxo) and peak period $(\mathrm{Tp})$ were obtained from Faro wave buoy (belonging to Instituto Hidrográfico), located $30 \mathrm{~km}$ to the East of the study area (Figure 1a) in a water depth of $93 \mathrm{~m}$ MSL. Overtopping parameters (flow depth and velocity) were measured along a profile in the middle section of the western breakwater (Figure $1 \mathrm{~b}$ and $\mathrm{c}$ ). Flow depth was measured with a series of pressure transducers along the breakwater crest. Video images from crest overtopping at the profile of instrumentation were recorded from a higher position at a nearby cliff $(100 \mathrm{~m}$ in horizontal distance, Figure 1b). Ground Control Points (GCPs) were placed and georeferenced to support overtopping flow analysis using video image.

\section{Nearshore wave propagation}

Offshore wave conditions were propagated to the breakwater toe (3.5 m below MSL) using SWAN (Simulating WAves Nearshore; Booij et al., 1999). Grid resolutions of $45 \mathrm{~m}$ and $5 \mathrm{~m}$ were chosen for the large and small grids, respectively (Figure 2).

Model predictions were initialized on the two open boundaries of the larger grid with the parametric input from the wave buoy time series, using a JONSWAP spectral shape to represent the wave field. Input boundary conditions for the small grid were determined from the computations over the large grid. SWAN simulations accounted for non-linear triad wave-wave interactions,

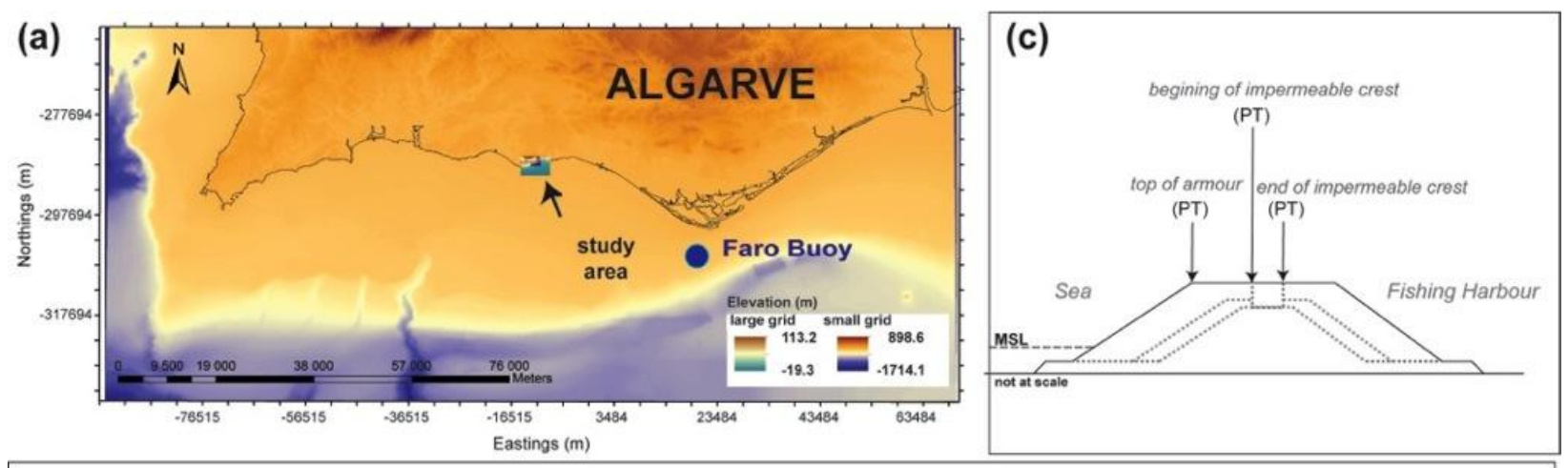

(b)
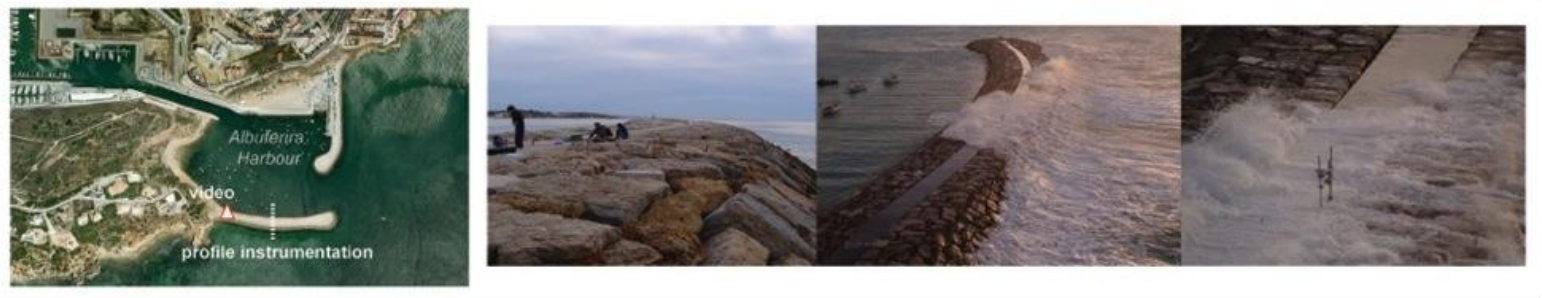

Figure 1. (a) Study area; (b) Albufeira Harbour and photos from fieldwork profile instrumentation and overtopping occurrence; and (c) Pressure transducers (PT) location across the breakwater profile. 


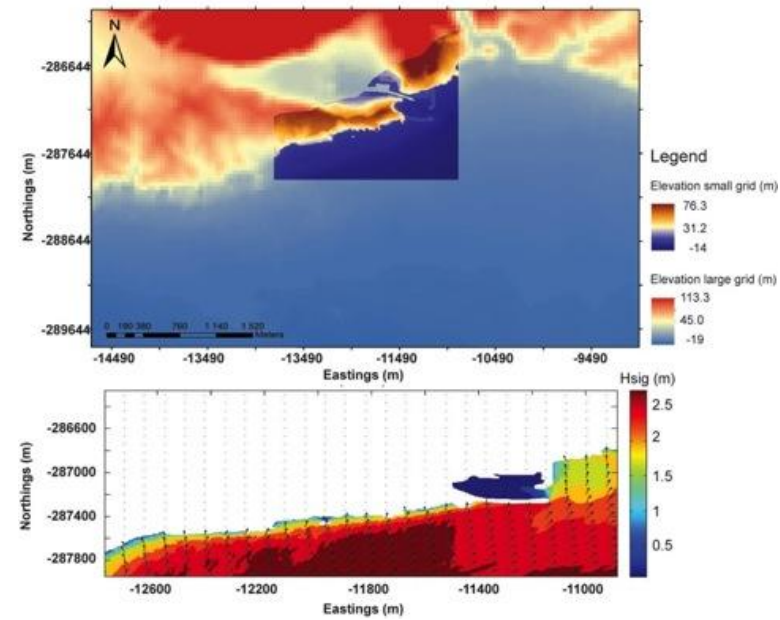

Figure 2. Nested grids used in SWAN runs (depths referred to MSL, upper panel). Significant wave height (Hs), and wave direction (arrows), during high tide (lower panel).

as they are rather important in shallow coastal areas (Booij et al., 1999; Holthuijsen, 2007), for bottom friction dissipation using the default variable JONSWAP expression according to Hasselmann et al. (1973), and for breaking dissipation according to the default bore-based model of Battjes and Janssen (1978).

Overtopping velocities and discharge computations

Each overtopping event was defined as a single passage of water above the structure crest. Data were collected at the top of the armour slope and at the beginning of the impermeable crest of the breakwater (distant $5.2 \mathrm{~m}$ ). These data were used to identify overtopping frequency, and to calculate flow depth and flow velocity.

The leading-edge flow velocity $\left(v_{f}\right)$ represents the water velocity between the sensors located at the top of the armour slope and at the beginning of the impermeable crest, and is obtained using the time delay between sensors:

$$
v f=\frac{d}{t f-t i}
$$

where $d$ is the horizontal distance between the sensors, $t i$ and $t f$ correspond to the arrival time at the top of the slope armour and the arrival time at the beginning of the impermeable crest, respectively. The leading-edge velocity, $v_{f}$, represents the mean velocity of each event. Besides, peak overtopping flow velocity $\left(v_{p}\right)$ was also computed by considering the difference between arrival times of maximum overtopping flow depths (peak):

$$
v p=\frac{d}{t p f-t p i}
$$

where tpi and tpf correspond to the arrival times at the top of the armour and at the beginning of the impermeable crest, respectively. Overtopping leading-edge volumes $\left(\mathrm{V}_{f}\right)$ and overtopping peak volumes $\left(\mathrm{V}_{\max }\right)$, were also calculated for all overtopping events, using the flow depths, flow velocities (leading-edge velocity and peak velocity) and the duration of each event.

\section{Empirical tools prediction}

Calculated mean overtopping discharges based on field measurements at the top of the armour (Qarmour) and at the beginning of the impermeable crest (Qcrest) were compared with mean discharges predicted by the EurOtop empirical formulae available

online

(http://www.overtoppingmanual.com/calculation_tool.html) and by the NN_OVERTOPPING2 tool (Coeveld et al., 2005) also available online. For comparison, the calculated mean overtopping discharges for each block of 30 minutes (Qarmour and Qcrest), were obtained by adding all event volumes and dividing by $1800 \mathrm{~s}$.

The geometrical characteristics of the structure adopted for the discharge prediction were defined according to six cross-sections measured around the instrumented profile. For the EurOtop formulae the structure geometry was assumed as "armoured composite slope with crest berm". The input wave parameters at the toe of the structure and the structure parameters are described in Ferreira et al. (2013). Input wave parameters for the $\mathrm{NN}_{-}$ OVERTOPPING2 tool included the wave data at the toe of the structure and the angle between the wave direction and the normal to the structure. Details about the NN_OVERTOPPING2 input parameters are presented in Coeveld et al. (2005). For both methods, EurOtop formulae and NN_OVERTOPPING2, the predicted mean overtopping discharges are provided per meter run of seawall.

\section{Hazard assessment}

Hazard assessment was conducted by comparing calculated mean overtopping discharges and maximum volumes, both based on filed measurements, with the values indicated in the EurOtop Manual (2007) and Geeraerts et al. (2007). The overtopping limits suggested in Table 1 derivate from a general precautionary principle based on observations and measurements undertaken by the CLASH project (Allsop et al., 2008). Above the presented limits, both humans and goods are at risk; risk to structure integrity is not evaluated here.

\section{RESULTS AND DISCUSSION}

Overtopping parameters (flow depths and flow velocities) were measured during neap tides and storm conditions (Hso $\sim 3-4 \mathrm{~m}$ and $\mathrm{Tp} \sim 8-10 \mathrm{~s}$, Figure 3), with dominant wave direction from $\mathrm{SW}$, frequent during winter. Maximum wind intensities were close to $7 \mathrm{~m} / \mathrm{s}$, occurring during high tide. For the analysis of the overtopping variability along the monitored tidal cycle, four blocks of 30 minutes, beginning at $05 \mathrm{~h}, 07 \mathrm{~h}, 08 \mathrm{~h}$ and $10 \mathrm{~h}$, were chosen; each time block represents different tide stages. The time block of $05 \mathrm{~h}$ represents the beginning of overtopping occurrence, whereas the time blocks of $07 \mathrm{~h}$ and $08 \mathrm{~h}$ are representative of high tide, and the time block of $10 \mathrm{~h}$ is representative of mid tide (Figure 3a).

\section{Overtopping frequency and associated discharges}

Overtopping flow was generally turbulent across the armour and the end of the impermeable crest of the breakwater, similar to 'white water' flow defined by Pullen et al. (2007). Indeed, most recorded flows are classified with mean Froude number of 9 (supercritical). The maximum overtopping duration was $5 \mathrm{~s}$, and mean overtopping flow depths were on average below $3 \mathrm{~cm}$ (Figure 4). There is no significant correlation between the flow depths and related velocities, which means that the higher velocities were not always related with deeper water flows. Mean $v_{f}$ and $v_{p}$ values are of the same order of magnitude, less than $6 \mathrm{~m} / \mathrm{s}$; maximum values obtained for $v_{f}$ are slightly higher than for $v_{p}$, due to differences in the methodology (Figure 4). Results for $v_{f}$ were corroborated with velocities obtained with video analysis (using wave arrival at each GCPs). The velocities obtained with 
Table 1. Indicated limits for overtopping mean discharges and peak volumes (adapted from Geeraerts et al., 2007).

\begin{tabular}{lll}
\hline \hline Hazard type/reason & $\begin{array}{l}\text { Mean } \\
\text { discharge }\end{array}$ & $\begin{array}{l}\text { Peak } \\
\text { volume }\end{array}$ \\
\hline Pedestrians & $\mathrm{Q}(1 / \mathrm{s} / \mathrm{m})$ & Vmax $(1 / \mathrm{m})$ \\
\hline $\begin{array}{l}\text { Unaware pedestrian, no clear } \\
\text { view of the sea, narrow } \\
\text { walkway or close proximity } \\
\text { to edge }\end{array}$ & $\mathrm{Q}>0.03$ & $\begin{array}{l}2-5 \text { at high } \\
\text { level or } \\
\text { velocity }\end{array}$ \\
\hline $\begin{array}{l}\text { Aware pedestrian, clear view } \\
\text { of the sea, wider walkway }\end{array}$ & $\mathrm{Q}>0.1$ & $\begin{array}{l}20-50 \text { at } \\
\text { high level or } \\
\text { velocity }\end{array}$ \\
\hline $\begin{array}{l}\text { Trained staff, well shod and } \\
\text { protected, overtopping flows } \\
\text { at lower levels only, no } \\
\text { falling jet, low danger of fall } \\
\text { from walkway }\end{array}$ & $\mathrm{Q}[1-10]$ & $\begin{array}{l}500 \text { at low } \\
\text { level }\end{array}$ \\
\hline Marinas & & \\
\hline $\begin{array}{l}\text { Sinking of small boats set 5- } \\
10 \text { m from wall, damage to } \\
\text { larger yachts }\end{array}$ & $\mathrm{Q}>10$ & $1000-10000$ \\
\hline $\begin{array}{l}\text { Significant damage or } \\
\text { sinking of larger yachts }\end{array}$ & $\mathrm{Q}>50$ & $5000-50000$ \\
\hline
\end{tabular}

video image were, on average $5 \mathrm{~m} / \mathrm{s}$, with maximum values of $12 \mathrm{~m} / \mathrm{s}$.

Larger overtopping volumes were recorded during high tide (07h and 08h, Table 2), as well as higher flow depths and higher velocities (Figure 4). The increased velocities might be partially ascribed to an increase in overtopping depth and also to an increase of wind velocity over that period. Wind affected incoming waves by blowing up-rushing water over the crest of the structure, resulting in a possible modification of the physical form of the overtopping volume or jet (Pullen et al., 2007), and ultimately, contributing to the total volume of overtopping. Wind also affects the way that hazard might be assessed (Shankar and Jayaratne, 2003; Allsop et al., 2008). Obtained records are, however, scarce to yield conclusions.

Except for $05 \mathrm{~h}$ time block, mean $\mathrm{V}_{\max }$ values are of higher magnitude than $\mathrm{V}_{f}$, indicating that this last method is more useful when describing individual maximum overtopping events, whereas $\mathrm{V}_{f}$ is mostly representative of average conditions. Mean $\mathrm{V}_{f}$ volumes are of the same order of magnitude as the individual discharges recorded in Pullen et al. (2003), at the Samphire Hoe (about $300 \mathrm{l} / \mathrm{s}$ to $500 \mathrm{l} / \mathrm{s}$ ) and the individual maximum discharges estimated by Hughes et al. (2012), in laboratory. However, Qarmour exceeds the mean overtopping discharges obtained at Zeebrugge by Geeraerts and Boone (2004), Q < 0.86 1/s/m for $\mathrm{Hmo}=3.9 \mathrm{~m}$ and $\mathrm{Tp}=8.6 \mathrm{~s}$, and Qarmour and Qcrest exceed the mean overtopping discharges obtained at Ostia, $\mathrm{Q}<0.361 / \mathrm{s} / \mathrm{m}$ for $\mathrm{Hmo}=2.0 \mathrm{~m}$ and $\mathrm{Tp}=9 \mathrm{~s}$ by De Rouck et al (2005), as can be seen in Table 3. The differences are due to the intrinsic differences between the structures, the wave conditions and, of course, also the type of data acquisition and methodology adopted for discharge computation.

\section{Calculated vs. predicted overtopping}

Maximum mean overtopping discharges predicted with the EurOtop formulae were $1.2 \mathrm{l} / \mathrm{s} / \mathrm{m}$ and $1.5 \times 10^{-1} \mathrm{l} / \mathrm{s} / \mathrm{m}$ at the top of the armour slope and at the beginning of the impermeable crest, respectively (Table 3). For the NN_OVERTOPPING2 tool, maximum mean overtopping discharges corrected to account for

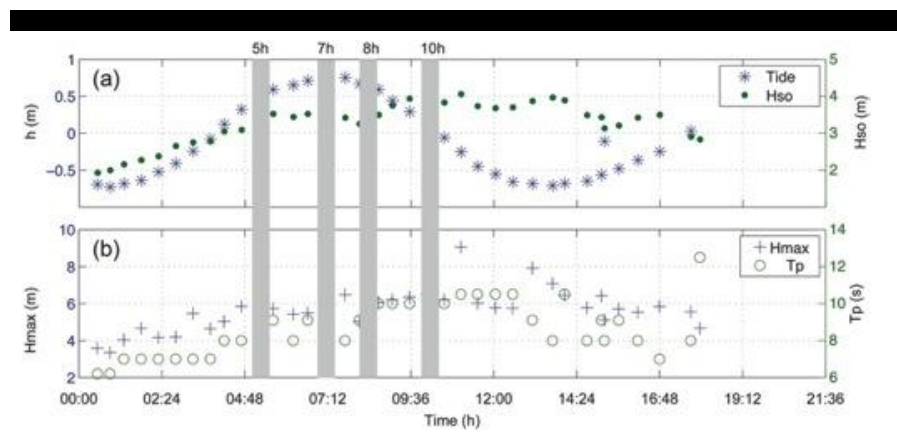

Figure 3. (a) Tide (h) and significant wave height (Hso) during fieldwork; (b) Maximum wave height (Hmax) and wave peak period (Tp) during fieldwork. Vertical grey bars mark $05 \mathrm{~h}, 07 \mathrm{~h}, 08 \mathrm{~h}$ and $10 \mathrm{~h}$ time blocks chosen for analysis of overtopping.

model, scale and wind effects in prototype situations, Q'_NN, were $1.8 \mathrm{1} / \mathrm{s} / \mathrm{m}$ at the top of the armour slope and $5.5 \times 10^{-1} \mathrm{l} / \mathrm{s} / \mathrm{m}$ at the beginning of the impermeable crest. Q'_NN and Q_NN exhibit a similar pattern (Figure 5).

NN_OVERTOPPING2 mean discharges presented relatively small variations along the studied period, while the calculated mean discharges based on field measurements revealed higher variability (Figure 5, left panel). At both locations (armour and crest), Q' NN predicted discharges present a good agreement with the calculated discharges (Qarmour and Qcrest), when considering the entire period of analysis, and are generally included in the $95 \%$ confidence intervals obtained from the NN_OVERTOPPING2 tool. Differences can be found when comparing each time block individually. At the top of the armour slope, the mean relative error between Qarmour and Q' $\mathrm{NN}$ is less than 1\%, whereas the maximum relative error is of $60 \%$. At the beginning of the impermeable crest, the mean relative error between Qcrest and Q'_NN is higher, about $20 \%$, whereas the maximum relative error is similar, $60 \%$. The correction applied by this tool improves significantly the agreement between predicted and calculated

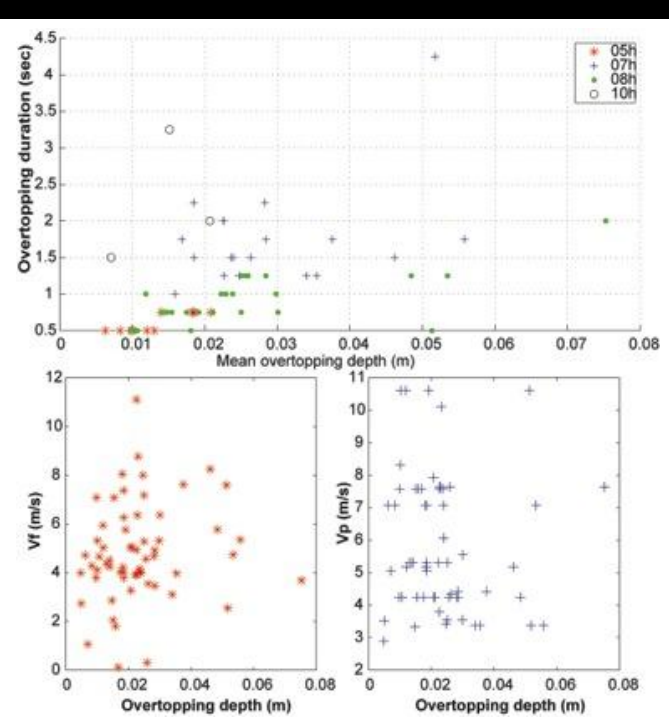

Figure 4. Overtopping duration vs. mean overtopping depth (upper panel); $v_{f}$ and $v_{p}$ vs. mean overtopping depth at the top of the breakwater armour slope (lower panel). 
Table 2. $\mathrm{V}_{f}$ and $\mathrm{V}_{\max }(\mathrm{l} / \mathrm{m})$ at the beginning of the impermeable crest of the breakwater.

\begin{tabular}{lcccc}
\hline \hline Parameters & \multicolumn{3}{c}{$\mathrm{V}_{f}$} \\
\hline & $05 \mathrm{~h}$ & $07 \mathrm{~h}$ & $08 \mathrm{~h}$ & $10 \mathrm{~h}$ \\
\hline Mean & 166 & 170 & 185 & 181 \\
\hline Max & 166 & 209 & 231 & 205 \\
\hline \multicolumn{5}{c}{$\mathrm{V}_{\max }$} \\
\hline Mean & 166 & 188 & 308 & 204 \\
\hline Max & 166 & 297 & 508 & 261 \\
\hline
\end{tabular}

\section{discharges (Figure 5).}

There is a fair agreement between Q' ${ }^{N N}$ and Qarmour, with three of the four data points included in-between $1 / 2<Q$ '_NN/Qarmour $<2$ (Figure 5, right panel). At the beginning of the impermeable crest, calculated mean overtopping discharges are also fairly predicted by NN_OVERTOPPING2 tool. In contrast, the probabilistic EurOtop formulae clearly underpredict the discharges at both locations, but especially at the impermeable crest, by one order of magnitude (Figure 5, right panel). Similar situation occurs for the uncorrected NN_OVERTOPPING2 results (Figure 5, left panel).

Deviations between fieldwork data and tools predictions can be partially explained by the natural wave variability, namely wavewave interaction near the structure (specifically due to reflected waves) and also by the important $3 \mathrm{D}$ processes that occur at the field including the longshore variability of the overwash progression through structure, induced by alongshore differences between wave crest and structure. Furthermore, the calculation of overtopping discharges from field measurements use tide levels and wave conditions at the structure predicted from measurements elsewhere, which might introduce some uncertainty. Moreover, most data used for developing the tools were obtained from physical model tests, where some scale effects affect the results and where 3D effects are often neglected. The 95\% confidence interval obtained from the NN_OVERTOPPING2 tool already accounts for differences on wave characteristics at the toe of the structure (before or after breaking, for example) and differences
Table 3. Results of mean overtopping discharges based on field measurements (Qarmour and Qcrest) and on predictions from NN_OVERTOPPING2 and EurOtop formulae (1/s/m).

\begin{tabular}{|c|c|c|c|c|c|}
\hline & Qarmour & Q_NN & $\begin{array}{l}\text { Q_NN } \\
(2.5 \%)\end{array}$ & $\begin{array}{c}\text { Q_NN } \\
(97.5 \%)\end{array}$ & $\mathrm{Q}_{-}^{\prime} \mathrm{NN}$ \\
\hline Min & $3.5 \times 10^{-01}$ & $2.1 \times 10^{-01}$ & $3.5 \times 10^{-02}$ & 1.3 & $5.5 \times 10^{-01}$ \\
\hline Max & 2.1 & 1.5 & $2.7 \times 10^{-01}$ & 6.6 & 1.8 \\
\hline & $\mathrm{Q}_{\text {crest }}$ & Q_NN & $\begin{array}{l}\text { Q_NN } \\
(2.5 \%)\end{array}$ & $\begin{array}{c}\text { Q_NN } \\
(97.5 \%)\end{array}$ & $\mathrm{Q}^{\prime} \mathrm{NN}$ \\
\hline Min & $1.8 \times 10^{-01}$ & $3.0 \times 10^{-02}$ & $5.4 \times 10^{-03}$ & $1.5 \times 10^{-01}$ & $1.9 \times 10^{-01}$ \\
\hline $\operatorname{Max}$ & $7.5 \times 10^{-01}$ & $2.2 \times 10^{-01}$ & $6.6 \times 10^{-02}$ & $7.9 \times 10^{-01}$ & $5.5 \times 10^{-01}$ \\
\hline \multicolumn{6}{|c|}{ EurOtop formulae } \\
\hline & & \multicolumn{2}{|c|}{$\mathrm{Q}_{\text {armour }}$} & \multicolumn{2}{|c|}{$\mathrm{Q}_{\text {crest }}$} \\
\hline & Min & \multicolumn{2}{|c|}{$1.9 \times 10^{-01}$} & \multicolumn{2}{|c|}{$1.7 \times 10^{-02}$} \\
\hline & Max & \multicolumn{2}{|c|}{1.2} & \multicolumn{2}{|c|}{$1.5 \times 10^{-01}$} \\
\hline
\end{tabular}

on the measurements due to scale effects. Other deviations between fieldwork data and tools predictions can also be explained by difficulties inherent to the field measurements.

Summing up, results from the corrected NN_OVERTOPPING2 (Q' $\mathrm{NN}$ ) are the best predictions for mean overtopping discharges calculated based on field measurements of flow depths and velocities (Figure 5).

\section{Hazard assessment}

Because in almost all instances, the use of empirical methods involves some degree of simplification of the actual situation, the hazard analysis of the monitored conditions is discussed based on the recorded field data only.

For the calculated mean overtopping discharges $(0.2<$ Qcrest $<0.8 \mathrm{l} / \mathrm{s} / \mathrm{m})$, the breakwater offers risk mostly to unaware and aware pedestrians $(\mathrm{Q}>0.1 \mathrm{l} / \mathrm{s} / \mathrm{m}$, Table 1$)$. However, for the calculated overtopping peak volumes $\left(166<\mathrm{V}_{\max }<508\right.$ $1 / \mathrm{m})$, the breakwater offers risk to all types of pedestrians $\left(\mathrm{V}_{\max }>500 \mathrm{l} / \mathrm{m}\right.$, Table 1), confirming visual observations during fieldwork and video monitoring. There was no related risk to small boat in the fishing harbour, since they were more than $20 \mathrm{~m}$
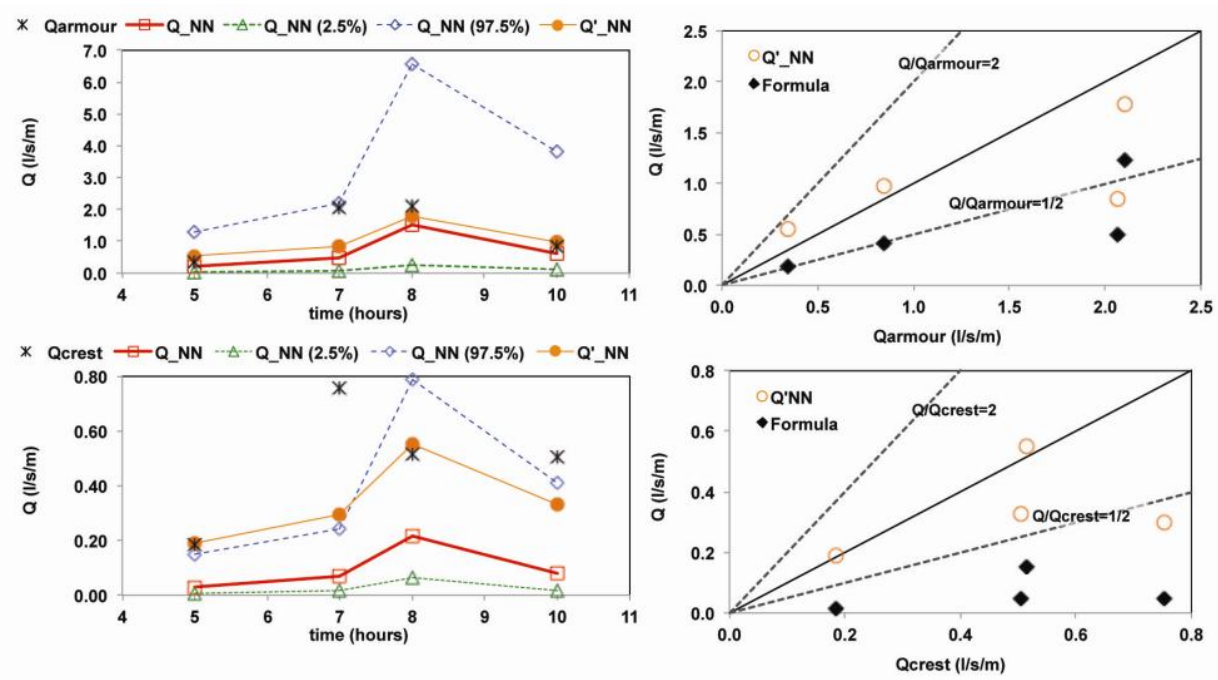

Figure 5. Comparison between calculated mean overtopping discharges based on field measurements at the top of the armour slope (Qarmour, upper panel) and at the beginning of the impermeable crest (Qcrest, lower panel), and NN_OVERTOPPING2 tool parameters (Q_NN, 95\% confidence intervals, Q_NN(2.5\%), Q_NN(97.5\%)) (left panel); and comparison between calculated mean overtopping discharges and results from both EurOtop formulae and the NN_OVERTOPPING2 tool Q'_NN (right panel). 
apart from the structure. There is a limitation when comparing the recorded hydrodynamic conditions with the classification from Table 1 since discharge intervals presented in Table 1 concern hazard assessment behind the breakwater, and the discharges presented here are related to measurements at the beginning of the impermeable crest, which seems more adequate to pedestrians at the walkway. Moreover, limits presented in Table 1 concern to overtopping velocities below $10 \mathrm{~m} / \mathrm{s}$ (Allsop et al., 2008). Individual maximum velocities recorded here were above $10 \mathrm{~m} / \mathrm{s}$ (Figure 4), therefore, lower volume intervals should be preferably used as guideline.

Differences between the calculated mean and maximum overtopping volumes $\left(\mathrm{V}_{f}\right.$ and $\mathrm{V}_{\max }$ in $1 / \mathrm{m}$, Table 2$)$, confirm the randomness of the overtopping spectrum (as suggested by Allsop et al. (2008)). In fact, in a precautionary management approach, individual maximums would be more adequate to characterise local overtopping hazard. Tests on the effects of overtopping flows on people suggest that values on mean discharges alone may not give reliable information (Allsop et al., 2008). Thus, an increased effort to develop methods to predict maximum volumes for the overall structure types, and their validation, should be performed. The methodology applied here allows the computation of both mean and maximum volume intervals. Although it was only validated for this breakwater, it is likely suitable to be adopted in other locations. Simultaneously, besides flow depths and overtopping discharges, research should also explore in more detail the overtopping hazard estimates based on overtopping velocities.

\section{CONCLUSIONS}

This paper presents a comparison of mean overtopping discharges calculated from flow field measurements of depths and velocities at a breakwater armour and crest, with mean discharges predicted by empirical tools. The corrected NN_OVERTOPPING2 is the method that better predicted the mean discharges calculated based on field data, for the overall analysed overtopping events, but presents significant errors when predicting individual mean discharges. EurOtop formula underpredicts calculated mean discharges, and is unsuitable to predict local overtopping volumes. Towards an increase of validation of the empirical/numerical tools (e.g., discharge predictions for short-term intervals) efforts should be concentrated on fieldwork data acquisition.

The recorded hydrodynamic conditions offer risk to all types of pedestrians at the walkway and to small boats, if located at less than $20 \mathrm{~m}$ of the breakwater. Hazard assessment has different results when using calculated mean overtopping discharges or overtopping peak volumes, thus it is recommended that peak volumes should be more often used as a parameter to infer local hazard. Future work should aim at the understanding and quantification of overtopping effects, in an attempted to solve structure design problems before construction.

\section{ACKNOWLEDGEMENTS}

This work is a contribution to the project SPACE (PTDC/ECM/114109/2009), funded by FCT. A. R. Carrasco was supported by SFRH/BPD/88485/2012. Ana Matias was supported by Programme Investigator FCT. This is also a contribution for the RUSH project (PTDC/CTE-GIX/116814/2010). Tidal data were kindly supplied by Puertos del Estado and offshore wave data by Instituto Hidrográfico.

\section{LITERATURE CITED}

Allsop, W., Bruce, T., Pullen, T. and van Der Meer, J., 2008. Direct Hazard from wave overtopping - the forgotten aspect of coastal flood risk assessment? DEFRA. Proceedings of Flood and Coastal Management Conference, Manchester, UK, $11 \mathrm{p}$.

Battjes, J.A. and Janssen, P.A.E.M., 1978. Energy loss and set-up due to breaking of random waves, Proceedings of 16th International Conference on Coastal Engineering, ASCE, 569-587.

Booij, N., Ris, R.C. and Holthuijsen, L.H., 1999. A third-generation wave model for coastal regions, Part I, Model description and validation, Journal of Geophysical Research, C4, 104, 7649-7666.

Chini, N. and Stansby, P.K., 2012. Extreme values of coastal wave overtopping accounting for climate change and sea level rise, Coastal Engineering, 65, 27-37.

Coeveld, E.M., Van Gent, M.R.A. and Pozueta, B., 2005. Neural Network. Manual NN OVERTOPPING 2. CLASH WP8, WL Delft Hydraulics Report, Delft, The Netherlands.

De Rouck, J., Geeraerts, J., Troch, P., Kortenhaus, A., Pullen, T. and Franco, L., 2005. New results on scale effects for wave overtopping at coastal structures. Proceedings of ICE Coastlines, Structures \& Breakwaters '05, Thomas Telford, London, 29-43.

Didier E., Ferreira O., Matias A., Neves M.G., Reis M.T. and Pacheco A., 2011. Desenvolvimento e validação de um modelo Smoothed Particle Hydrodynamics para aplicação a estruturas costeiras. Proceedings of 7as Jornadas Portuguesas de Engenharia Costeira e Portuária, eds. Delegação Portuguesa da PIANC, pp 30 (15 p. CD Rom), Porto, Portugal.

Ferreira, Ó., Reis, M.T., Carrasco, A.R., Neves, M.G., and Didier, E., 2013. Small Overtopping discharges at Albufeira Harbour: field measurements and modelling. Proceedings of 6th SCACR International Short Course/Conference on Applied Coastal Research, LNEC, Lisboa.

Geeraerts, J. and Boone, C., 2004. CLASH: Full Scale Measurements on the Zeebrugge breakwater - Second Winter Season, Ghent University, Belgium.

Geeraerts, J., Troch, P., Rouck, J.D., Verhaeghe, H. and Bouma, J.J., 2007. Wave overtopping at coastal structures: prediction tools and related hazard analysis. Journal of Clear Production, 15, 1514-1521.

Hasselmann, K., Barnett, T.P., Bouws, E., Carlson, H., Cartwright, H., Cartwright, D.E., Enke, K., Ewing, J.A., Gienapp, H., Hasselmann, D.E.,Kruseman, P., Meerburg, A., Muller, P., Olbers, D.J., Richter, K. Sell, W. and Walden, H., 1973. Measurements of wind-wave growth and swell decay during the Joint North Sea Wave Project (JONSWAP). Dtsch. Hydrogr. Z. Suppl. 12 (A8), 1-95.

Holthuijsen, L.H., 2007. Waves in Oceanic and Coastal Waters, Cambridge University Press.

Hughes, S., Thornton, C., van der Meer, J. and Scholl, B., 2012. Improvements in describing wave overtopping processes. Proceedings of 3rd International Conference Coastal Engineering (ICCE), ASCE, Santander, Spain, 1-6.

Pullen, T., Allsop, N.W.H., Bruce, T. and Geeraerts, J., 2003. Violent wave overtopping: CLASH field measurements at Samphire Hoe. Proceeding of Coastal Structures, $12 \mathrm{p}$.

Pullen, T., Allsop, N.W.H., Bruce, T., Kortenhaus, A., Schu $\square$ ttrumpf, H. And Van der Meer, J.W., 2007. EurOtop: Wave Overtopping of Sea Defences and Related Structures: Assessment Manual. Environment Agency, UK, Expertise Netwerk Waterkeren, NL, and Kuratorium fur Forschung im Kusteningenieurwesen, DE.

Shankar, N.J. and Jayaratne, M.P.R., 2003. Wave run-up and overtopping on smooth and rough slopes of coastal structures. Ocean Engineering, 30, 221-238.

Tonelli, M. and Petti, M., 2013. Numerical simulation of wave overtopping at coastal dikes and low crested structures by means of a shock-capturing Boussinesq model. Coastal Engineering, 79, 75-88.

Van der Meer, J.W., Snijders, W., and Regeling, H.J. 2006. The wave overtopping simulator. Proceedings of 30th International Conference Coastal Engineering, ASCE, San Diego, 4654-4679.

Verhaeghe, H., 2005. Neural Network Prediction of Wave Overtopping at Coastal Structures. PhD Thesis, Gent University, Belgium. 